\title{
Sytuacja prawna małoletnich rodziców w zakresie możliwości sprawowania władzy rodzicielskiej ${ }^{1}$
}

\author{
The legal situation of minor parents with regards to the possibility \\ of exercising parental authority \\ Правовое положение несовершеннолетних родителей \\ по возможности осуществления родительских прав \\ ANNA URBAŃSKA-ŁUKASZEWICZ \\ Dr, Instytut Nauk Prawnych Polskiej Akademii Nauk \\ e-mail: a.urbanska-lukaszewicz@inp.pan.pl, https://orcid.org/0000-0003-0513-2240
}

\begin{abstract}
Streszczenie: Celem badań było dokonanie analizy sytuacji prawnej małoletnich rodziców w zakresie możliwości sprawowania przez nich władzy rodzicielskiej i uprawnień w stosunku do dziecka. Należy zauważyć, że małoletni rodzice na gruncie prawa są jeszcze „dziećmi”. Pozostają bowiem do osiągnięcia pełnoletności, pod władzą rodzicielską swoich rodziców lub pod opieką. Nie przysługuje im także władza rodzicielska nad swoim dzieckiem. Ustawodawca przewidział, że matka dziecka może uzyskać pełnoletność, a tym samym władzę rodzicielską po ukończeniu 16. roku życia i zawarciu małżeństwa za zgodą sądu. Uprawnienie takie nie przysługuje małoletniemu ojcu dziecka. Małoletni rodzice posiadają uprawnienia związane z samym faktem bycia rodzicami. Należy do nich prawo do osobistych kontaktów z dzieckiem. Uczestniczą oni też w sprawowaniu bieżącej pieczy nad osobą dziecka i w jego wychowaniu, chyba że sąd opiekuńczy ze względu na dobro dziecka postanowi inaczej.
\end{abstract}

Słowa kluczowe: małoletni rodzice, władza rodzicielska, zawarcie małżeństwa, opieka, bieżąca piecza, wychowanie, zgoda sądu

Summary: The aim of the research was to analyze the legal situation of minor parents in terms of the possibility of exercising parental authority and rights in relation to the child. It should be noted that minor parents are still "children" by law. They remain until the age of majority, under the parental authority of their parents or under their care. They are also not entitled to parental responsibility for their child. The legislator provided that the child's mother may obtain the age of majority, and thus parental authority, after reaching the age of 16 and entering into marriage with the consent of the court. Such a right is not granted to the minor father of the child.

Key words: minor parents, parental responsibility, marriage, custody, ongoing custody, upbringing, court approval

Резюме: В статье анализируется правовое положение несовершеннолетних родителей в рамках их возможности реализовать родительские права и обязанности в отношении ребенка. По закону несовершеннолетние все еще являются «детьми», поскольку до достижения совершеннолетия, в их отношении применяются родительские права, или они остаются под попечением своих родителей. Такие родители не обладают родительскими правами в отношении своего ребенка. Согласно действующему законодательству, мать ребенка может достичь совершеннолетия и, соответственно, получить родительские права по достижении 16 лет и вступлении в брак с согласия суда. Аналогичное право не предоставляется несовершеннолетнему отцу ребенка. Несовершеннолетние родители наделены правами, связанными

1 Artykuł opublikowany w ramach grantu projektu badawczego nr 2015/19/B/HS5/03014 pt. Małoletni wobec rodziców i państwa. Współczesne, polskie uwarunkowania prawe realizacji zasad dobra dziecka oraz partycypacji. 
с самим фактом того, что они являются родителями, например, правом на личный контакт с ребенком. Они также участвуют в осуществлении текущего попечения над ребенком и в его воспитании, если суд по вопросам опеки и попечительства не примет иного решения в интересах ребенка.

Ключевые слова: несовершеннолетние родители, родительские права, заключение брака, опека, попечение, воспитание, согласие суда

\section{Wstęp}

Celem moich badań było dokonanie wszechstronnej analizy sytuacji prawnej małoletnich rodziców, a w szczególności odpowiedź na pytanie, jakie uprawnienia przysługują im w stosunku do ich dziecka. Tematyka ta jest obszerna, dlatego została podzielona na dwa artykuły. Pierwszy dotyczy możliwości sprawowania przez małoletnich rodziców władzy rodzicielskiej, a drugi kwestii ustalenia pochodzenia dziecka i przysposobienia.

Konstytucja RP zobowiązuje państwo do ochrony macierzyństwa i rodzicielstwa (art. 18 Konstytucji RP). Ochrona ta odnosi się do każdego przypadku rodzicielstwa, $w$ tym także rodzicielstwa małoletnich osób ${ }^{2}$. Ze swej natury rodzicielstwo dotyczy relacji rodziców z dziećmi. Mając to na względzie, należy też podkreślić szczególną ochronę praw dziecka. Artykuł 72 Konstytucji RP zapewnia dziecku prawo do życia w rodzinie, co oznacza prawo do przebywania wraz z matką, ojcem i rodzeństwem ${ }^{3}$.

Omawiane w artykule regulacje dotyczą zarówno relacji pomiędzy małoletnimi rodzicami a ich dziećmi, jak i pomiędzy małoletnimi rodzicami a ich rodzicami. W badaniach koncentrowano uwagę na realizacji zasady dobra dziecka, a także na partycypacji dziecka w sprawach, które go dotyczą.

Dobro dziecka to ustalenie optymalnej konfiguracji dotyczącego dziecka stanu rzeczy (jego interesów) ${ }^{4}$. W omawianym zakresie dobro nowonarodzonego dziecka oznacza prawo do życia w rodzinie, kontaktów z rodzicami, zaspokojenie jego potrzeb egzystencjalnych, a także zabezpieczanie jego innych prawnych interesów.

2 M. Andrzejewski, Podstawy prawne ochrony macierzyństwa w Polsce. Status prawny małoletnich i nieletnich matek, w: Sytuacja prawna, społeczna $i$ wychowawcza nieletnich ciężarnych i nieletnich matek przebywających $w$ placówkach resocjalizacyjnych. Raport $z$ realizacji projektu "Chcę być $z$ Toba MAMO!", red. A. Sikora, Warszawa 2013, s. 85.

3 M. Andrzejewski, Piecza zastępcza, w: System prawa prywatnego, t. 12. Prawo rodzinne i opiekuńcze, red. T. Smyczyński, Warszawa 2011, s. 435 i nast.; tenże, Ochrona praw dziecka w rodzinie dysfunkcyjnej (dziecko - rodzina - państwo), Kraków 2003, s. 163 i nast.

4 T. Sokołowski, Prawo rodzinne. Zarys wykładu, Poznań 2010, s. 13. 
Dobro małoletnich rodziców również wymaga uregulowania sytuacji prawnej z ich małoletnim dzieckiem, zapewnianiu im możliwości partycypacji w jego życiu i kontaktów.

Należy zauważyć, że małoletni rodzice na gruncie prawa są jeszcze „dziećmi”. Pozostają bowiem do osiągnięcia pełnoletności pod władzą rodzicielską swoich rodziców lub pod opieką. Osoba małoletnia to taka, która nie ma ukończonych 18 lat, nie ma zdolności do czynności prawnych (do 13. roku życia) albo ma ją w ograniczonym zakresie (13-18 lat). Nie przysługuje jej także władza rodzicielska nad swoim dzieckiem. Zwrócić należy uwagę, że dziecko występuje w niniejszym opracowaniu zarówno, gdy mowa o małoletnich rodzicach, jak i o nowo narodzonym człowieku.

\section{Małoletni rodzice - dane statystyczne}

Przejście do szczegółowych rozważań poprzedzić należy danymi statystycznymi, które pokazują skalę problemu badawczego. Według raportu Głównego Urzędu Statystycznego „Dzieci w Polsce” w 2014 r. mediana wieku kobiet rodzących dziecko wyniosła 29,5 lat wobec 26,1 lat w 2000 r. (w 1990 r. było to niewiele mniej, bo 26 lat, natomiast w 1980 r. mediana wynosiła 23 lata). Podwyższył się średni wiek urodzenia pierwszego dziecka do 27,4 lat w 2014 r. (w 1990 r. wynosił 23 lata, a w 2000 r. niespełna 24$)^{5}$. Najmłodsze matki to dziewczynki w wieku 12 lat $^{6}$ - są to pojedyncze zdarzenia i mają miejsce - średnio - co 2-3 lata. Natomiast dziewczynek, które rodziły w wieku 13-14 lat, jest już znacznie więcej - ok. 50-60 rocznie. W 2014 r. dzieci urodzone przez matki w wieku 19 lat i mniej (dane zawierają zatem także matki, które są już rok pełnoletnie) stanowiły 3,5\% wszystkich urodzeń. Pozytywną stroną tej sytuacji jest sukcesywny spadek odsetka urodzeń przez matki w tak młodym wieku - na początku lat 90. ubiegłego wieku stanowiły one ok. $8 \%$.

W Roczniku Demograficznym przygotowanym za 2017 r. wskazano, że urodzonych dzieci przez dziewczynki, które nie kończyły 15. roku życia było 212, 16-latki

5 Dzieci w Polsce w 2014 roku. Charakterystyka demograficzna, https://stat.gov.pl/obszary-tematyczne/ ludnosc/ludnosc/dzieci-w-polsce-w-2014-roku-charakterystyka-demograficzna,20,1.html, s. 5; Dzietność kobiet w latach 1960-2016, https://stat.gov.pl/obszary-tematyczne/ludnosc/ludnosc/struktura-ludnosci,16,1.html [dostęp: 7.05.2021 r.].

6 P. Szukalski, Urodzenia nastolatek, Demografia i Gerontologia - Biuletyn Informacyjny 2016, nr 6, s. 3, http://dspace.uni.lodz.pl [dostęp: 7.05.2021 r.]. 
urodziły 614 dzieci, a 17-latki - 1492. Dane statystyczne pokazują, że zdarzają się przypadki, iż małoletnie matki mają więcej niż jedno dziecko ${ }^{7}$.

Ten sam Rocznik pokazuje, że 1000 chłopców w wieku do 19. roku życia zostało ojcami ${ }^{8}$. Dane te nie ukazują jednak pełnego obrazu skali zjawiska małoletnich ojców ${ }^{9}$, gdyż statystyka uwzględnia wyłącznie ojców, którzy już są pełnoletni. Nie wiadomo też, czy informacje te obejmują ojców, którzy uznali ojcostwo albo prawomocnie zakończyła się sprawa o sądowe ustalenie ojcostwa, czy są to dane przygotowane wyłącznie w oparciu o twierdzenia matek. Liczba małoletnich ojców może być zatem zdecydowanie większa.

Powyższe liczby wskazują, że rodzicielstwo małoletnich jest ważnym problemem społecznym. Wśród wielu jego przyczyn wskazać należy zwłaszcza na podejmowanie przedwczesnych stosunków płciowych przez osoby psychicznie niedojrzałe, które szukają pewnego rodzaju rekompensaty, potwierdzenia własnej wartości, a także odreagowanie samotności i słabych relacji z osobami najbliższymi ${ }^{10}$. Niezaspokajanie potrzeb emocjonalnych dziecka prowadzi do jego zaburzeń w tej sferze. Przedwczesne stosunki płciowe mogą z kolei doprowadzić do nieplanowanych i niepożądanych ciąż ${ }^{11}$. Należy też wskazać na szeroki problem rozluźnienia więzi społecznych, rodzinnych, przez co część młodzieży źle rozumie pojęcie wolności, kieruje się modą, przyjemnością, postawą konsumpcjonizmu i jest bardzo podatna na sugestie grupy rówieśników ${ }^{12}$. Nie bez znaczenia pozostaje także wpływ mediów i kreowanego tam wizerunku świata ${ }^{13}$. Zauważa się też, że nastolatkowie dojrzali są jedynie płciowo do poczęcia dziecka pod względem biologicznym, ale nie są przygotowani pod względem psychicznym i społecznym ${ }^{14}$.

\footnotetext{
7 Rocznik Demograficzny 2018, https://stat.gov.pl/obszary-tematyczne/roczniki-statystyczne/roczniki-statystyczne/rocznik-demograficzny-2018,3,12.html, s. 269 [dostęp: 7.05.2021 r.].

8 Tamże, s. 276.

$9 \quad$ Ł.P. Ratajczak, Ojcostwo $w$ doświadczeniach niepetnoletnich chłopców, Poznań 2016, s. 86.

10 U. Kempińska, Małżeństwa młodocianych. Przyczyny i konsekwencje, Włocławek 2005, s. 48-49.

11 Tamże, s. 52.

12 Tamże.

13 Ł.P. Ratajczak, Rodzicielstwo niepełnoletnich osób, w: Socjalizacja dysocjacyjna w doświadczeniu indywidualnym i społecznym. Inspiracje teoretyczne próby pedagogicznych ingerencji, red. A. Matysiak-Błaszczyk, J. Modrzewski, Poznań-Kalisz 2012, s. 225-226.

$14 \quad$ Ł.P. Ratajczak, Ojcostwo $w$ doświadczeniach..., s. 88.
} 


\section{Ciąża jako przyczyna zawarcia małżeństwa?}

Pełnoletnim jest, kto ukończył lat osiemnaście, a ponadto małoletnia, która zawarła związek małżeński ${ }^{15}$. Małżeństwo jest zatem dla kobiety drogą do wcześniejszego uzyskania pełnoletności. Zawarcie związku małżeńskiego i założenie rodziny wymaga od nupturientów dojrzałości: fizycznej, psychicznej i społecznej ${ }^{16}$.

Władza rodzicielska przysługuje tylko osobom pełnoletnim. Oznacza to, że małoletni rodzice nie posiadają władzy rodzicielskiej nad swoim dzieckiem. Osoba, której powierza się pieczę nad dzieckiem, sama powinna bowiem posiadać odpowiednie doświadczenie życiowe i umiejętność podejmowania rozsądnych decyzji. Przyjęto, że pełnoletność stanowi właściwe kryterium formalne pozwalające na pozytywną ocenę w tym zakresie ${ }^{17}$. Małoletni rodzice uzyskują władzę rodzicielską automatycznie $\mathrm{z}$ chwilą, gdy odpadną przeszkody w jej posiadaniu, czyli z dniem uzyskania pełnoletności ${ }^{18}$.

Osiągnięcie pełnoletności jest możliwe nie tylko wskutek osiągnięcia odpowiedniego wieku, ale również poprzez zawarcie małżeństwa przez małoletnią kobietę. Regułą jest, że nie można zawrzeć małżeństwa przed ukończeniem lat osiemnastu (art. $10 \$ 1$ Kodeksu rodzinnego i opiekuńczego; dalej: K.r.o.). Jednakże z ważnych powodów sąd opiekuńczy może zezwolić na zawarcie małżeństwa kobiecie, która ukończyła lat szesnaście, a z okoliczności wynika, że zawarcie małżeństwa będzie zgodne $\mathrm{z}$ dobrem założonej rodziny. Prawo to nie dotyczy małoletnich mężczyzn. Małoletni ojciec nie może zatem wcześniej uzyskać władzy rodzicielskiej nad swoim dzieckiem. W literaturze przedmiotu sporne jest, czy rozwiązanie to jest zgodne $\mathrm{z}$ konstytucyjną zasadą równouprawnienia kobiet i mężczyzn (art. 33 ust. 1 Konstytucji) ${ }^{19}$.

Przeszkoda zawarcia małżeństwa ma charakter względny i może być usunięta w drodze zezwolenia sądu, po spełnieniu łącznie wymaganych przez prawo przesłanek

15 P. Nazaruk, w: Kodeks cywilny. Komentarz, red. J. Ciszewski, P. Nazaruk, 2019 [baza danych LEX], Art. 10.

16 U. Kempińska, Małżeństwa młodocianych. Przyczyny..., s. 33.

17 J. Strzebińczyk, Władza rodzicielska, w: System Prawa Prywatnego, t. 12. Prawo rodzinne i opiekuńcze, red. T. Smyczyński, Warszawa 2003, s. 245.

18 J. Ignatowicz, w: Kodeks rodzinny i opiekuńczy z komentarzem, red. J. Pietrzykowski, Warszawa 2012, s. 409.

19 K. Pietrzykowski (Kodeks rodzinny i opiekuńczy. Komentarz, red. K. Pietrzykowski, Warszawa 2003, s. 190) uważa to rozwiązanie za niezgodne z Konstytucją RP, natomiast T. Smyczyński, (Prawo rodzinne i opiekuńcze, Warszawa 2018, s. 55) oraz W. Borysiak (Kodeks rodzinny i opiekuńczy. Komentarz, red. J. Wierciński, Warszawa 2014, s. 105) uważają, że rozróżnienie to nie może być uznane za naruszające konstytucyjną zasadę równouprawnienia małżonków. 
(ukończenie szesnastego roku życia, wystąpienie ważnych powodów oraz sformułowanie pozytywnej prognozy, że zawarcie małżeństwa będzie zgodne z dobrem założonej rodziny). W literaturze podaje się, że do ważnych powodów należy:

1) urodzenie dziecka przez małoletnią matkę,

2) ciąża,

3) istniejąca między osobami zamierzającymi zawrzeć związek małżeński, trwająca od dłuższego czasu relacja, nasuwająca poważne prawdopodobieństwa zajścia kobiety w ciążę ${ }^{20}$.

Z powyższego wynika, że wszystkie wymienione wyżej przyczyny związane są z macierzyństwem kobiety.

W każdej sprawie konieczne jest zbadanie, czy małżeństwo będzie zgodne z dobrem założonej rodziny, co wyraża się przede wszystkim w prawidłowym jej funkcjonowaniu. Sąd powinien odmówić wyrażenia zezwolenia, jeżeli uzna, że pożycie małżeńskie szybko ulegnie rozkładowi albo gdy cechy osobiste jednego lub obojga nupturientów zagrażają ich związkowi (np. nadużywanie alkoholu, narkotyków). Samo stwierdzenie ciąży u małoletniej nie wystarcza do udzielenia jej zezwolenia na zawarcie małżeństwa. Konieczne jest także ustalenie, że zamierzone małżeństwo nie nasuwa uzasadnionych zastrzeżeń z punktu widzenia dobra założonej rodziny, dobra małoletniej i przyszłych dzieci ${ }^{21}$.

Wnioski z przeprowadzonych badań empirycznych, dotyczących trwałości małżeństw zawieranych za zgodą sądu, nasuwają obawę, że istnieje presja dotycząca zawarcia małżeństwa, co może przyspieszyć znacząco wejście w dojrzałe życie osób, które nie są jeszcze psychicznie i społecznie w pełni ukształtowane. Bardzo często małoletnim trudno pogodzić się z obowiązkami, na które nieopatrznie siebie narazili i z których ciężaru i ważności nie zdawali sobie sprawy ${ }^{22}$. Zadaniem sądu jest więc zbadanie gotowości przyszłych rodziców do założenia rodziny i podjęcia odpowiedzialności za siebie i dziecko. W konsekwencji bowiem małoletnia matka nabędzie pełną zdolność do czynności prawnych i władzę rodzicielską szybciej niż jej rówieśnicy. W niektórych przypadkach być może zaistnieje potrzeba poczekania na osiągnięcie pełnoletności wraz z ukończeniem lat osiemnastu.

Przed wydaniem postanowienia $\mathrm{w}$ zakresie wyrażenia zgody na zawarcie małżeństwa sąd zobowiązany jest wysłuchać wnioskodawczynię, osobę, z którą

20 K. Pietrzykowski, w: Kodeks rodzinny i opiekuńczy. Komentarz ..., red. K. Pietrzykowski, s. 191; W. Borysiak, w: Kodeks rodzinny..., red. J. Wierciński, s. 106-107.

21 Orzeczenie SN z dnia 6 października 1958, III CO 19/58, OSN 1960, nr 1, poz. 21; W. Borysiak, w: Kodeks opiekuńczy..., s. 107.

22 L. Mościcka, Diagnoza i prognoza trwałości małżeństw zawieranych za zgodą sq̨du, Wrocław 1982, s. $49-50$. 
małżeństwo ma być zawarte, oraz w razie potrzeby osoby bliskie przyszłych małżonków (art. $561 \S 3$ zd. 2 Kodeksu prawa cywilnego; dalej: K.p.c.). Są to przede wszystkim rodzice nupturientów, którzy mogą pomóc sądowi ustalić, czy małżeństwo będzie zgodne z dobrem przyszłej rodziny. Zarówno aprobata, jak i dezaprobata rodziców dla zamysłu zawarcia przez ich dziecko małżeństwa nie wiąże sądu, podlega tylko ocenie na tle całokształtu zebranego materiału i okoliczności spra$w^{23}$. Małoletnia matka uczestniczy zatem w postępowaniu, które dotyczy jej osoby. Może samodzielnie złożyć wniosek w sądzie, a także popierać go w toku postępowania. Sąd bada też, czy udzielenie zezwolenia będzie zgodne z dobrem dziecka, tj. małoletniej matki, jak i jej dziecka. Jeżeli wniosek jest składany już po narodzinach dziecka, to w toku postępowania sąd może wysłuchać jego opiekuna. W celu prawidłowego wydania postanowienia sąd ma możliwość przeprowadzenia $\mathrm{z}$ urzędu także innych dowodów, np. dowodu $z$ opinii biegłego.

Sąd udzielając zezwolenia, wskazuje osobę, z którą małżeństwo ma być zawarte (art. $561 \S 3$ zd. 1 K.p.c.), gdyż zezwala on na małżeństwo z konkretną osobą, a nie ogólnie, pozwalając małoletniej dokonać wyboru później. Zwrócić należy jednak uwagę, że mężczyzna nie musi być ojcem dziecka małoletniej matki. Strony mogą zawrzeć małżeństwo dopiero po uprawomocnieniu się orzeczenia, jednak już wcześniej mogą złożyć przed kierownikiem urzędu stanu cywilnego przewidziane w art. 4 K.r.o. zapewnienia, że nie wiedzą o istnieniu okoliczności wyłączających zawarcie tego małżeństwa ${ }^{24}$.

Jak pokazują statystki sądowe, w 2016 r. 75 kobiet zawarło związek małżeński w wieku 16 lat oraz 153 kobiety w wieku 17 lat ${ }^{25}$. Roczna liczba spraw związanych Z wyrażeniem zgody na zawarcie małżeństwa, rozpatrywanych przez sądy systematycznie spada, jednakże nadal jest znacząca. W 2008 r. takich postępowań toczyło się w Polsce 1391, w 2010 r. - 913, w 2011 r. - 716, w 2012 r. - 616, 2013 r. - 601, 2014 r. $-538^{26}$.

Z badań Instytutu Wymiaru Sprawiedliwości ${ }^{27}$ w zakresie wyrażenia przez sąd zezwolenia na zawarcie małżeństwa wynika, że średni wiek wnioskodawczyń

23 J. Winiarz, J. Gajda, Prawo rodzinne, Warszawa 2001, s. 53.

24 A. Zieliński, w: Kodeks postępowania cywilnego. Komentarz, red. A. Zieliński, Warszawa 2008, s. 963.

25 Rocznik Demograficzny 2017, https://stat.gov.pl/obszary-tematyczne/roczniki-statystyczne/roczniki-statystyczne/rocznik-demograficzny-2017,3,11.html, s. 204 [dostęp: 7.05.2021 r.].

26 Rocznik statystyczny sądownictwa powszechnego i wojskowego 2010-2104, Warszawa 2015, s. 76; M. Domański, Zezwolenie na zawarcie małżeństwa kobiecie, która nie ukończyła 18 lat (raport z badania akt sq̨owych), w: Stosowanie prawa. Ksiega jubileuszowa z okazji XX-lecia Instytutu Wymiaru Sprawiedliwości, red. A. Siemaszko, Warszawa 2011, s. 321.

27 Instytut Wymiaru Sprawiedliwości wylosował do badań 63 sądy rejonowe z całej Polski. Otrzymał 95 akt z 47 sądów. W pozostałych sądach nie prowadzono spraw, o które prosił Instytut. 
wynosił 16 lat i 5 miesięcy ${ }^{28}$. Najmłodsza uczestniczka miała 15 lat i 2 miesiące, mimo iż kobieta w chwili wydania postanowienia musi mieć ukończone 16 lat. Nie jest jednak konieczne, aby ten wiek był ukończony w momencie składania wniosku. W 70,5\% spraw wnioskodawczynie deklarowały, że są na utrzymaniu rodziców, w 11,6\% na utrzymaniu narzeczonych. W 7,4\% postępowań małoletnie matki przebywały w domu dziecka. Badania wykazały silne uzależnienie finansowe małoletnich matek od swoich rodziców i słabą zdolność do utrzymania rodziny przez kandydata na przyszłego małżonka. Okoliczności te powinny być i są brane przy udzielaniu przez sąd zezwolenia na zawarcie małżeństwa ${ }^{29}$.

Sąd powinien też dokładnie ustalić cechy oraz sposób życia kandydatów na małżonków, np. czy pracują albo uczą się. Badania pokazały też, że stan cywilny przyszłych małżonków sądy zbadały tylko w 21,1\% spraw, w 70\% spraw nie przeprowadzono dowodu na potwierdzenie sytuacji zawodowej mężczyzny, poprzestając na jego oświadczeniu. W 65,3\% spraw sąd w ogóle nie zapytał o karalność mężczyzny $^{30}$. Z badań wynikało także, że w 78,9\% postępowań wnioskodawczynie były w chwili wszczęcia postępowania w ciąży, w 16,8\% spraw urodziły już dziecko ${ }^{31}$. $\mathrm{W}$ jednej sprawie wnioskodawczyni urodziła dziecko i ponownie była w ciąży ${ }^{32}$.

Sądy powinny badać także, czy zawarcie małżeństwa będzie zgodne z dobrem zakładanej rodziny. Zadaniem sądu jest zatem ustalenie sytuacji osobistej każdego z nupturientów, ich wzajemnego stosunku do siebie, ustalenie, czy przyszłe małżeństwo może być trwałe, czy będzie prawidłowo funkcjonowało, a także ocena sytuacji materialnej i perspektywy źródła dochodu. Poza tym sąd powinien ustalić stopień dojrzałości psychicznej, społecznej i fizycznej kobiety, informacje dotyczące mężczyzny (jego środowisko, sposób życia), stosunek rodziców przyszłych nupturientów do zawarcia małżeństwa, ocenić sytuacją majątkową i materialną ${ }^{33}$. Ten ostatni aspekt, czyli ustalenie materialnej podstawy przyszłej rodziny, sprawdzany był w $82,4 \%$ spraw.

Sądy kontrolują powyższe okoliczności poprzez np. wywiad środowiskowy (68\% spraw), a także wysłuchanie małoletniej (97,8\%), mężczyzny (96,7\%), rodziców małoletniej (91,2\%), rodziców mężczyzny (16\%). W niektórych sprawach sądy wysłuchały też inne osoby, np. dyrektora domu dziecka, babcię, kuratora przeprowadzającego wywiad środowiskowy (4 sprawy). W 10 postępowaniach w aktach

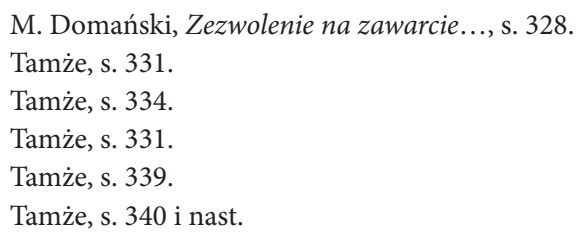


znajdowało się zaświadczenie o stanie zdrowia, z czego w 2 z nich dokumenty dotyczyły zdrowia psychicznego. W 2 sprawach skierowano strony na badanie do biegłego psychologa albo istniejących $\mathrm{w}$ trakcie przeprowadzania badań rodzinnych ośrodków diagnostyczno-konsultacyjnych.

Z powyższego wynika, że sądy dokonywały oceny, czy małżeństwo będzie zgodne $\mathrm{z}$ dobrem rodziny w zasadzie w oparciu o wysłuchanie zainteresowanych. Praktyka sądów jest zatem schematyczna. Zakładają one, że skoro małoletnia jest w ciąży, to zawarcie małżeństwa będzie zgodne $\mathrm{z}$ dobrem zakładanej rodziny ${ }^{34}$. Sądy bardzo rzadko korzystały z dowodu z opinii biegłego, która mogłaby mu dostarczyć wiadomości specjalnych, np. ustalenia stopnia dojrzałości psychicznej nupturientów do założenia rodziny.

Zwrócić należy uwagę, że jest wiele opracowań dotyczących trwałości takich małżeństw i wszystkie one zawierają tezę, że niestety ich stałość jest niewielka. Trwają krótko, kończąc się rozstaniem lub formalnym rozwodem już ok. roku po zawarciu ${ }^{35}$. Spośród poddanych badaniom 125 par 37 rozwiodło się, a 13 pozostawało w separacji ${ }^{36}$. W 2016 r. rozwiodły się 293 kobiety, które zawarły związek małżeński w wieku 16 lat, oraz 850 kobiet, które zawarły związek małżeński w wieku 17 lat ${ }^{37}$. Jako przyczynę takiego stanu rzeczy wskazuje się na zbyt młody wiek nupturientów, a tym samym słabą znajomość przyszłego małżonka, jego rodziny, a także brak przygotowania do pełnienia roli małżeńsko-rodzicielskich ${ }^{38}$. Sądy powinny zatem dokładniej sprawdzać sytuację małoletniej matki i gotowość nupturientów do założenia rodziny poprzez przeprowadzenie postępowania dowodowego polegającego na szczegółowym przesłuchaniu stron zamierzających zawrzeć związek małżeński, ich rodziców lub innych osób bliskich. Sąd może też przeprowadzić wywiad kuratora, dowód z opinii biegłego psychologa oraz dowody z dokumentów potwierdzających sytuację materialną przyszłej rodziny i karalność nupturientów.

Kobieta, która po ukończeniu szesnastego roku życia zawarła związek małżeński, nawet jeżeli uczyniła to bez zezwolenia sądu, uzyskuje pełnoletność. Zasługuje na uwagę również fakt, że zawarcie małżeństwa przez osobę małoletnią może nastąpić także i w innych okolicznościach, np. na podstawie dokumentów, których treść nie wskazuje rzeczywistego stanu rzeczy, w szczególności na podstawie sfałszowanego zezwolenia sądu lub dokumentów stwierdzających pełnoletność osoby

\footnotetext{
34 Tamże, s. 354.

35 U. Kempińska, Małżeństwa młodocianych. Ciąża, ślub i co dalej...?, Toruń 2012, s. 21-24; 157 i nast.;

L. Mościcka, Diagnoza i prognoza...; U. Kempińska, Małżeństwa młodocianych. Przyczyny...

U. Kempińska, Małżeństwa młodocianych. Przyczyny..., s. 118.

Rocznik Demograficzny 2017..., s. 243.

U. Kempińska, Małżéstwa młodocianych. Ciąża, ślub..., s. 164.
} 
w rzeczywistości jeszcze niepełnoletniej. Małżeństwo takie jest ważnie (skutecznie) zawarte, ponieważ art. 10 K.r.o. nie powoduje jego nieważności ex lege. W tej sytuacji nastąpi także uzyskanie pełnoletności, ponieważ konstytutywne znaczenie ma w tym względzie zawarcie małżeństwa ${ }^{39}$.

Jeżeli doszło do zawarcia małżeństwa mimo braku przepisanego wieku, unieważnienia małżeństwa może żądać każdy z małżonków oraz prokurator (art. 10 $\$ 2$ K.r.o., art. 22 K.r.o.). Legitymacja czynna męża jest jednak ograniczona w przypadkach, w których kobieta zaszła w ciążę, niezależnie od tego, czy fakt ten nastąpił przed czy po zawarciu małżeństwa. Istotne jest, aby ciąża istniała w czasie trwania małżeństwa ${ }^{40}$.

Małżeństwo zawarte wbrew przeszkodzie wieku ulega konwalidacji, jeżeli powództwo o unieważnienie takiego małżeństwa nie zostało wniesione przed ukończeniem przez małżonka osiemnastu lat ${ }^{41}$.

Osiągniecie pełnoletności powoduje uzyskanie przez małoletnią matkę władzy rodzicielskiej. Uzależnienie powstania władzy rodzicielskiej małoletniej od zawarcia związku małżeńskiego i to niekoniecznie $\mathrm{z}$ drugim rodzicem poddano krytyce. Zwrócono uwagę, że skutek określony w art. $10 \$ 2$ Kodeksu cywilnego (dalej: K.c.) nastąpi niezależnie od tego, kto będzie małżonkiem małoletniej, a fakt zawarcia małżeństwa nie decyduje o stopniu rozwoju ani o zdobytym doświadczeniu życiowym i nie gwarantuje należytego wykonywania władzy rodzicielskiej. Ponadto przy założeniu podobnego lub identycznego stopnia rozwoju małoletnich rodziców w tym samym wieku jednemu będzie przysługiwała władza rodzicielska, a innemu nie ${ }^{42}$.

W literaturze zadano pytanie „czy należy (czy prawo powinno) sugerować małoletniej matce, by wychodziła za mąż, bo to wzmocni jej status prawny, w tym umożliwi sprawowanie władzy rodzicielskiej nad swym dzieckiem, w sytuacji gdy kandydat na męża to z reguły osoba przypadkowa, równie nieprzygotowana do odpowiedzialnego rodzicielstwa, jak matka dziecka?"43. Zwrócono uwagę, że polskie ustawodawstwo takie właśnie rozwiązanie sugeruje i dokłada do problemu

39 M. Watrakiewicz, Wiek a zdolność do czynności prawnych, Kwartalnik Prawa Prywatnego 2003, z. 3, s. 510-512; T. Sokołowski, w: Kodeks cywilny. Komentarz, t. 1. Część ogólna, red. A. Kidyba, 2012 [baza danych LEX], Komentarz do art. 10, teza 5.

40 Orzeczenie SN z dnia 23 kwietnia 1968 r., II CR 77/68, OSN 1968, nr 77.

41 W. Borysiak, w: Kodeks rodzinny..., red. J. Wierciński, s. 114-115.

42 J. Strzebińczyk, Władza rodzicielska..., s. 246.

43 M. Andrzejewski, Podstawy prawne..., s. 90; M. Andrzejewski, Relacja rodzice i inne osoby dorosłe a dzieci w świetle nowych przepisów Kodeksu rodzinnego i opiekuńczego i niektórych innych ustaw (wybrane problemy), Acta Iuris Stetinensis 2014, nr 6, s. 379-380; M. Andrzejewski, Prawna ochrona macierzyństwa młodocianych matek, w: Współczesne problemy Prawa rodzinnego i spadkowego, red. M. Andrzejewski, K. Dadańska, Szczecin 2014, s. 23-41. 
przedwczesnej ciąży także kwestię zbyt wczesnego i często równie przypadkowego małżeństwa ${ }^{44}$. Ponadto obecna regulacja, pozwalająca małoletniej matce uzyskać władzę rodzicielską na skutek zawarcia związku małżeńskiego, kłóci się z ideą swobody zawierania małżeństw ${ }^{45}$.

Krytyce należy poddać obowiązujący stan prawny, zgodnie z którym małoletniej matce nie przysługuje władza rodzicielska bez konieczności zawarcia związku małżeńskiego. W literaturze przedmiotu zauważa się, że rozwiązanie to godzi w małoletnie matki i nie jest korzystne dla dziecka zarówno wtedy, gdy pełnoletni ojciec uznał ojcostwo, jak i w sytuacji, gdy wyznaczono dla dziecka opiekuna ${ }^{46}$. Przedstawiono także postulat, aby przyznać małoletniej matce władzę rodzicielską po ukończeniu 16. roku życia. Nie przesądzałoby to jednak o uzyskaniu pełnoletności, a atrybut przedstawicielstwa dziecka musiałby wykonywać ojciec albo ustanowiony kurator ${ }^{47}$. Zgodnie z innym poglądem warto uzupełnić K.r.o. o przepis upoważniający sąd opiekuńczy do przyznania małoletniej matce władzy rodzicielskiej, jeżeli ukończyła ona 16. rok życia ${ }^{48}$ i przemawiałaby za tym opinia psychologiczna, socjalna oraz medyczna. Na tej podstawie sąd oceniałby dojrzałość matki do sprawowania władzy rodzicielskiej ${ }^{49}$.

Powyższe rozwiązanie mogłoby również znaleźć zastosowanie do małoletnich ojców, którzy uznali ojcostwo albo ich ojcostwo zostało ustalone na mocy orzeczenia sądu. Małoletni ojciec, podobnie jak matka, mógłby sprawować władzę rodzicielską po ustaleniu przez sąd rodzinny, że jest on osobą wystarczająco dojrzałą. Małoletni ojciec również może sprawować bieżącą pieczę nad dzieckiem, a także uczestniczyć w jego wychowaniu. Sąd powinien mieć także możliwość, aby jemu przyznać władzę rodzicielską.

Podsumowując, z ważnych powodów sąd opiekuńczy może zezwolić na zawarcie małżeństwa kobiecie, która ukończyła lat szesnaście, gdy z okoliczności wynika, że zawarcie małżeństwa będzie zgodne z dobrem założonej rodziny. Ważne powody z reguły związane są z ciążą kobiety. Małżeństwo jest dla kobiety drogą do wcześniejszego uzyskania pełnoletności i tym samym władzy rodzicielskiej. Rozwiązanie to jest krytykowane, gdyż jest to jedyna możliwość, aby uzyskać władzę rodzicielską. Sam fakt zawarcia małżeństwa nie decyduje o stopniu rozwoju ani o zdobytym doświadczeniu życiowym i nie gwarantuje należytego wykonywania

\footnotetext{
44 M. Andrzejewski, Podstawy prawne..., s. 90.

45 Tamże, s. 90-91.

46 J. Strzebińczyk, Władza rodzicielska..., s. 246.

47 Tamże.

48 T. Sokołowski, Władza rodzicielska nad dorastającym dzieckiem, Poznań 1987, s. 129, 149.

49 M. Andrzejewski, Podstawy prawne..., s. 90-91.
} 
tej władzy. Uzyskanie pełnoletności nastąpi niezależnie od tego, kto będzie małżonkiem małoletniej.

Warto natomiast uzupełnić K.r.o. o przepis upoważniający sąd opiekuńczy do przyznania małoletnim rodzicom władzy rodzicielskiej, jeżeli ukończyli oni 16. rok życia, a zgromadzony materiał dowodowy, w tym opinie psychologiczna, socjalna oraz medyczna, przemawia za tym, że są wystarczająco dojrzali do sprawowania władzy rodzicielskiej ${ }^{50}$.

\section{Władza rodzicielska}

Małoletni rodzice dziecka do osiągnięcia pełnoletności pozostają pod władzą rodzicielską swoich rodziców ${ }^{51}$. Nie przysługuje im władza rodzicielska w stosunku do ich nowo narodzonego dziecka. Władza rodzicielska przysługuje bowiem tylko osobom posiadającym pełną zdolność do czynności prawnych, czyli pełnoletnim i nieubezwłasnowolnionym.

Nieprzyznanie małoletnim rodzicom, zarówno matce, jak i ojcu, władzy rodzicielskiej tłumaczy się tym, że osoba sprawująca pieczę nad dzieckiem sama powinna posiadać odpowiednie doświadczenie życiowe i możliwość podejmowania rozsądnych decyzji, a zdolność do czynności prawnych stanowi właściwe kryterium oceny ${ }^{52}$.

W przypadku rodziców posiadających pełną zdolność do czynności prawnych władza rodzicielska powstaje ex lege z chwilą urodzenia dziecka ${ }^{53}$. Małoletnia matka uzyskuje ją również automatycznie, ale z chwilą uzyskania pełnoletności ${ }^{54}$. Małoletni ojciec, aby uzyskać władzę rodzicielską po osiągnieciu pełnoletności, musi uznać ojcostwo albo uzyskać prawomocne orzeczenie o sądowym ustaleniu ojcostwa. Jeżeli pełnoletni ojciec uznał ojcostwo, gdy kobieta była w ciąży, to również nabędzie

\footnotetext{
50 Tamże.

51 Problematyczne jest zagadnienie oddziaływania bezpośredniego lub pośredniego na sytuację nienarodzonego dziecka, np. zabiegi prenatalne czy leczenie małoletniej, które może oddziaływać na nasciturusa. Problem ten, z uwagi na jego obszerność, wykracza poza ramy artykułu. Zob. T. Sokołowski, Sytuacja prawa małoletniej matki przed urodzeniem dziecka, Ruch Prawniczy, Ekonomiczny i Socjologiczny 1995, z. 2, s. 1-9.

52 Tamże.

53 Jest to pogląd dominujący, mimo iż kodeks wyraźnie nie wskazuje tego momentu. Pojawiają się jednak wątpliwości co do sytuacji rodzinnoprawnej nienarodzonego jeszcze dziecka, czego przykładem może być np. terapia prenatalna. J. Haberko, Cywilnoprawna ochrona dziecka poczętego a zastosowanie procedur medycznych, Warszawa 2010.

54 J. Ignatowicz, w: Kodeks rodzinny i opiekuńczy z komentarzem..., red. J. Pietrzykowski, s. 409.
} 
władzę z chwilą urodzenia dziecka. Jedynie małoletnia matka może uzyskać władzę rodzicielską przed ukończeniem 18. roku życia. Drogą do tego jest zawarcie związku małżeńskiego.

Małoletni rodzice nie mogą zatem podejmować żadnych decyzji związanych z dzieckiem, wyrażać zgody na zabiegi lecznicze, decydować o kwestiach światopoglądowych (np. udzielenie sakramentu chrztu) ani reprezentować go przed sądem. Ustawodawca przyznał jednak wszystkim małoletnim rodzicom możliwość uczestnictwa w sprawowaniu bieżącej pieczy nad osobą dziecka i w jego wychowaniu. $\mathrm{Z}$ uwagi na wiek dziecka do bieżącej pieczy nad jego osobą zalicza się przede wszystkim zaspokajanie jego codziennych potrzeb związanych z pielęgnacją noworodka, karmieniem, zabawami ${ }^{55}$. W wyjątkowych wypadkach sąd opiekuńczy ze względu na dobro dziecka może rodziców tego prawa pozbawić (art. $96 \$ 2$ K.r.o.) ${ }^{56}$. W literaturze zauważono, że z reguły wykonywanie bieżącej pieczy przez matkę dziecka, także małoletnią, jest zgodne $\mathrm{z}$ jego dobrem ${ }^{57}$. Ingerencja sądu może być uzasadniona w szczególności „wadliwą postawą małoletniej matki, a zwłaszcza jej zniechęceniem do wykonywania pieczy lub istotnym i trwałym zaniedbywaniem obowiązków względem dziecka, a także spowodowaniem poważnego zagrożenia jego dobra" ${ }^{58}$.

Omawiane uprawnienie nie tworzy nowej postaci władzy rodzicielskiej. Nie przyznaje też roszczenia o „dopuszczenie” do współwykonywania władzy rodzicielskiej ${ }^{59}$. Stwarza jedynie prawną podstawę współudziału małoletnich rodziców $\mathrm{w}$ wykonywaniu pieczy, wychowywaniu i reprezentacji dziecka przez drugiego z rodziców, któremu przysługuje władza rodzicielska, albo przez opiekuna dziecka. Jest to prawo podmiotowe małoletnich rodziców, które można uznać za przejaw „praw rodzicielskich", o których mowa w art. 48 ust. 2 Konstytucji RP ${ }^{60}$.

Władzy rodzicielskiej nikt poza rodzicami wykonywać nie może, dlatego w przypadku gdy żadnemu z nich ona nie przysługuje, ustanawia się dla dziecka opiekę ${ }^{61}$. Sytuacja taka zachodzi, gdy oboje rodzice są małoletni, jak i wówczas, gdy matka jest małoletnia, a ojcostwo nie zostało ustalone.

\footnotetext{
55 T. Sokołowski, Władza rodzicielska..., s. 23.

56 T. Sokołowski, w: Kodeks rodzinny i opiekuńczy. Komentarz, red. H. Dolecki, T. Sokołowski, Warszawa 2013, s. 655-656.

57 Tamże, s. 656.

58 Tamże.

59 J. Ignaczewski, Pochodzenie dziecka i władza rodzicielska po nowelizacji. Art. 619-1136 KRO, Warszawa 2009, s. 164.

60 A. Golec-Grzymek, Uwagi do nowelizacji Kodeksu rodzinnego i opiekuńczego z 6.11.2008 r., Monitor Prawniczy 2009, nr 19, s. 1049.

61 J. Ignatowicz, w: Kodeks rodzinny i opiekuńczy z komentarzem..., red. J. Pietrzykowski, s. 402.
} 
Małoletni rodzice mają jednak uprawnienia związane $\mathrm{z}$ faktem bycia rodzicami. Należy do nich prawo do osobistych kontaktów z dzieckiem. Nie jest ono elementem władzy rodzicielskiej, lecz prawem osobistym, dlatego też przysługuje również osobom, którym ta władza z jakiegokolwiek powodu nie przysługuje (art. 113 K.r.o.) ${ }^{62}$. Prawo do osobistej styczności z dzieckiem należy rozumieć szeroko, a więc jako przede wszystkim możliwość przebywania z dzieckiem i bezpośredniego porozumiewania się z nim ${ }^{63}$. Formy komunikacji pośredniej będą wykorzystywane na późniejszym etapie rozwoju dziecka. Styczności małego dziecka z matką jest jego podstawową potrzebą, która stwarza mu poczucie bezpieczeństwa ${ }^{64}$. Wyłącznie w wyjątkowych przypadkach, ze względu na dobro małoletniego dziecka, sąd może zakazać takich kontaktów, np. gdy ich utrzymywanie zagraża jego życiu, zdrowiu lub bezpieczeństwu ${ }^{65}$.

Ustawodawca nakłada na rodziców i dzieci obowiązek wzajemnego wspierania się (art. 87 K.r.o.). Nowo narodzone dziecko nie może wykazać wzajemności tego obowiązku, lecz spoczywa on wyłącznie na rodzicach. Obowiązek nie pozostaje w związku $\mathrm{z}$ władzą rodzicielską ${ }^{66}$, powstaje on $\mathrm{z}$ samego faktu urodzenia dziecka i z łączącej rodziców i dzieci więzi psychicznej.

W przypadku gdy tylko jeden rodzic jest małoletni, władza rodzicielska przysługuje drugiemu. Jednakże ojciec uzyskuje ją dopiero od momentu uprawomocnienia się orzeczenia o ustaleniu ojcostwa lub złożenia oświadczenia o uznaniu i jego potwierdzeniu przez matkę. W tej sytuacji do czasu osiągnięcia pełnoletności przez matkę ojciec będzie jedynym przedstawicielem ustawowym dziecka. Sprawa o sądowe ustalenie ojcostwa toczy się najczęściej z powodu sporu o ojcostwo pomiędzy matką a domniemanym ojcem. Postawić można zatem pytanie, czy ojciec dziecka, któremu przysługuje władza rodzicielska z momentem uprawomocnienia się wyroku o sądowym ustaleniu ojcostwa, będzie ją należycie sprawował ${ }^{67}$. Jeżeli sąd poda w wątpliwość kompetencje rodzicielskie i dobro dziecka będzie tego wymagało, to może w wyroku ustalającym ojcostwo orzec o zawieszeniu, ograniczeniu lub pozbawieniu władzy rodzicielskiej jednego lub obojga rodziców (art. $93 \$ 2$ K.r.o.). Wydanie takiego rozstrzygnięcia jest niezależne od wniosku stron i następuje z urzędu ${ }^{68}$.

\footnotetext{
62 E. Trybulska-Skoczelas, w: Kodeks rodzinny i opiekuńczy. Komentarz..., red. J. Wierciński 2014, s. 765-767.

63 Por. nowelizację art. $113 \$ 2$ K.r.o.

64 M. Bidzan, Nastoletnie rodzicielstwo. Perspektywa psychologiczna, Gdańsk 2013, s. 169.

65 Postanowienie SN z dnia 7 listopada 2000 r., I CKN 1115/2000, OSNC 2001, nr 3, poz. 50.

66 H. Haak, Władza rodzicielska. Komentarz, Toruń 1995, s. 9.

67 J. Ignatowicz, w: Kodeks rodzinny i opiekuńczy z komentarzem..., red. J. Pietrzykowski, s. 411; H. Haak, Pochodzenie dziecka. Komentarz, Toruń 1997, s. 145.

68 E. Trybulska-Skoczelas, w: Kodeks rodzinny..., red. J. Wierciński, s. 697.
} 
Sąd powinien kierować się przede wszystkim dobrem dziecka i rozważyć, czy ojciec daje gwarancję należytego wykonywania władzy rodzicielskiej ${ }^{69}$.

Ojciec, któremu przysługuje władza rodzicielska, powinien przy jej wykonywaniu działać w porozumieniu z małoletnią matką jego dziecka oraz liczyć się z jej stanowiskiem (art. $96 \$ 2$ K.r.o.) Ignorowanie decyzji matki, odnoszące się zwłaszcza do sposobu pielęgnacji małego dziecka, jest $\mathrm{z}$ reguły niezgodne $\mathrm{z}$ dobrem dziecka i może uzasadniać ograniczenie jego władzy rodzicielskiej ${ }^{70}$.

Jeżeli ojciec dziecka, któremu przysługuje władza rodzicielska, w rażący sposób zaniedbuje swoje obowiązki, może tej władzy zostać pozbawiony. Każdy, komu znane są zdarzenia uzasadniające wszczęcie postępowania przez sądu z urzędu, obowiązany jest zawiadomić o nich sąd opiekuńczy (art. 572 K.p.c.). Obowiązek ten spoczywa także na małoletniej matce. Sąd może wszcząć postępowanie z urzędu m.in. wówczas, gdy zachodzi potrzeba ograniczenia albo pozbawienia władzy rodzicielskiej. W tych przypadkach sąd wydaje odpowiednie zarządzenia.

Małoletnim rodzicom $\mathrm{z}$ racji swojego wieku nie przysługuje władza rodzicielska, lecz uczestniczą w sprawowaniu bieżącej pieczy nad dzieckiem i jego wychowaniu (art. $96 \$ 2$ K.r.o.). Rozwiązanie to należy ocenić pozytywnie, gdyż powala budować im więź z dzieckiem i zaspokaja poczucie bliskości. Małoletnim rodzicom przysługuje także prawo do kontaktów z dzieckiem. Jeżeli tylko jeden z rodziców jest małoletni, to władza rodzicielska przysługuje wyłącznie drugiemu.

\section{Opiekun nowo narodzonego dziecka}

Jeżeli władza rodzicielska nie przysługuje żadnemu z rodziców, ustanawia się dla dziecka opiekę (art. $94 \$ 3$ K.r.o.). Jest ona surogatem władzy rodzicielskiej i polega na sprawowaniu pieczy nad osobą i majątkiem dziecka, a także na jego reprezentowaniu (art. 155 K.r.o.) ${ }^{71}$. Ustanawia i kontroluje jej wykonanie sąd, który może czynić to z urzędu (art. 570 K.p.c.). Do czasu ustanowienia opiekuna sąd wydaje niezbędne zarządzenia dla ochrony osoby lub majątku dziecka, jeżeli jego dobro tego wymaga. W szczególności może ustanowić w tym celu kuratora.

69 T. Sokołowski, Prawo rodzinne..., s. 113-114.

70 T. Sokołowski, w: Kodeks cywilny. Komentarz, t. 1. Czesść ogólna, red. A. Kidyba, 2012 [baza danych LEX] Komentarz do art. 15, teza 12.

71 H. Dolecki, w: Kodeks rodzinny i opiekuńczy. Komentarz, red. H. Dolecki, T. Sokołowski, Warszawa 2013, s. 963. 
Nawet wówczas, gdy dziecko pozostaje pod dobrą opieką faktyczną (np. małoletniej matki i jej rodziców), należy ustanowić opiekę. Wynika to z zasady powszechności opieki i obowiązku jej ustanowienia ${ }^{72}$. Opiekunem małoletniego powinna zostać ustanowiona przede wszystkim osoba wskazana przez ojca lub matkę, jeżeli nie byli pozbawieni władzy rodzicielskiej (art. 149 K.r.o.). Małoletni nie zostali pozbawieni władzy rodzicielskiej, gdyż w ogóle im nie przysługiwała, dlatego mogą w toku postępowania wskazać osobę, która będzie sprawowała obowiązki opieku$\mathrm{na}^{73}$. Jeżeli opiekunem nie może zostać wskazana osoba albo sąd uzna, że z uwagi na dobro dziecka nie może ona pełnić obowiązków, wówczas opiekun powinien zostać ustanowiony spośród krewnych lub innych osób bliskich pozostającego pod opieką albo jego rodziców. W przypadku braku takich osób sąd opiekuńczy zwraca się o wskazanie odpowiedniej osoby do właściwej jednostki organizacyjnej pomocy społecznej albo do organizacji społecznej, do której należy piecza nad małoletnimi (art. $149 \$ 3$ K.r.o.).

Gdy ustanie przyczyna ustanowienia opieki, to wygasa ona $\mathrm{z}$ mocy prawa (art. 170 K.r.o. $)^{74}$. Nie jest potrzebne wydanie orzeczenia $\mathrm{w}$ tym zakresie. Jedną z przesłanek wygaśnięcia opieki jest przywrócenie władzy rodzicielskiej, a także uzyskanie przez rodziców zdolności do czynności prawnych albo ustalenie pochodzenia dziecka od pełnoletniego ojca ${ }^{75}$. W omawianych sytuacjach rodzice bądź jeden $\mathrm{z}$ nich uzyskują władzę rodzicielską i od tego momentu mają prawo i obowiązek wykonywania pieczy nad osobą i majątkiem dziecka oraz jego reprezentowania.

Opieka powinna być sprawowana z należytą starannością, tak jak tego wymaga dobro pozostającego pod opieką i interes społeczny. Opiekun nie ma pełnej dowolności w podejmowaniu ważnych spraw dotyczących osoby lub majątku małoletniego. Nie może on sam decydować np. o zabiegach leczniczych czy sprzedaży majątku podopiecznego. Powinien on uzyskać zezwolenia sądu na dokonanie tych czynności (art. 156 K.r.o.).

Należy rozważyć, czy małoletni rodzice mogą wpływać na sytuację ich dziecka i działania opiekuna. Do zadań opiekuna należy piecza nad osobą i majątkiem dziecka, a także jego reprezentacja. Opiekun ma obowiązek informować rodziców, którzy nie mają pełnej zdolności do czynności prawnych, ale uczestniczą w sprawowaniu bieżącej pieczy nad osobą dziecka i w jego wychowaniu, o decyzjach w ważniejszych sprawach, które dotyczą osoby lub majątku podopiecznego

\footnotetext{
72 T. Sokołowski, Prawo rodzinne..., s. 363.

73 J. Sadomski, w: Kodeks rodzinny i opiekuńczy. Komentarz, red. J. Wierciński, Warszawa 2014, s. 1005.

74 G. Jędrejek, Kodeks rodzinny i opiekuńczy. Komentarz aktualizowany, 2019 [baza danych LEX].

75 J. Strzebińczyk, Prawo rodzinne, Warszawa 2013, s. 389.
} 
(art. 158 K.r.o. $)^{76}$. Rozwiązanie to pozwala rodzicom uczestniczyć w życiu swojego dziecka. Przykładowo opiekun powinien poinformować rodziców o złożeniu wniosku do sądu o udzielenie zezwolenia na dokonanie określonej czynności prawnej. Opiekun nie jest związany opinią rodziców co do planowanej czynności. Jednakże sąd opiekuńczy po ustaleniu, że małoletni rodzice sprawują bieżącą pieczę nad dzieckiem, powinien wezwać ich do udziału w sprawie (art. $510 \$ 2$ K.p.c.). Małoletni rodzice stają się wówczas uczestnikiem postępowania sądowego ${ }^{77}$. Rozwiązanie to ma na celu ułatwienie małoletnim sprawowania władzy rodzicielskiej po osiągnięciu pełnoletności, gdyż mogą nabrać potrzebnego doświadczenia.

\section{Zakończenie}

1. Rodzicielstwo, także osób małoletnich, podlega szczególnej ochronie prawnej. Konstytucja RP zobowiązuje państwo do ochrony macierzyństwa i rodzicielstwa. Na gruncie prawa małoletni rodzice są jeszcze „dziećmi”, gdyż pozostają oni, aż do osiągnięcia pełnoletności, pod władzą rodzicielską swoich rodziców lub pod opieką.

2. Władza rodzicielska przysługuje tylko osobom pełnoletnim. Oznacza to, że małoletnim rodzicom nie przysługuje władza rodzicielska nad swoim dzieckiem. Ustawodawca przewidział, że matka dziecka może uzyskać pełnoletność, a tym samym władzę rodzicielską po ukończeniu 16. roku życia i zawarciu małżeństwa za zgodą sądu. $Z$ ważnych powodów sąd opiekuńczy może zezwolić na zawarcie małżeństwa kobiecie, która ukończyła lat szesnaście, a z okoliczności wynika, że zawarcie małżeństwa będzie zgodne z dobrem założonej rodziny.

3. Osiągniecie pełnoletności powoduje uzyskanie przez małoletnią matkę władzy rodzicielskiej. Uzależnienie powstania władzy rodzicielskiej małoletniej od zawarcia związku małżeńskiego i to niekoniecznie z drugim rodzicem należy poddać krytyce. Warto uzupełnić K.r.o. o przepis upoważniający sąd opiekuńczy do przyznania małoletnim rodzicom władzy rodzicielskiej, jeżeli ukończyli oni 16. rok życia, a zgromadzony materiał dowodowy, w tym opinie psychologiczna, socjalna oraz medyczna, przemawia za tym, że są wystarczająco dojrzali do sprawowania władzy rodzicielskiej.

\footnotetext{
76 T. Smyczyński, Prawo rodzinne..., s. 370.

77 G. Jędrejek, Kodeks rodzinny i opiekuńczy...
} 
4. Małoletni rodzice posiadają uprawnienia związane z samym faktem bycia rodzicami. Należy do nich prawo do osobistych kontaktów z dzieckiem. Uczestniczą oni też w sprawowaniu bieżącej pieczy nad osobą dziecka i w jego wychowaniu, chyba że sąd opiekuńczy ze względu na dobro dziecka postanowi inaczej.

5. Jeżeli władza rodzicielska nie przysługuje żadnemu z rodziców, ustanawia się dla dziecka opiekę. Opiekun powinien informować małoletnich rodziców o decyzjach w ważniejszych sprawach, które dotyczą osoby lub majątku podopiecznego.

6. Przygotowując nowe przepisy z zakresu omawianej tematyki, rozważyć należy uniezależnienie uzyskania władzy rodzicielskiej od zawarcia związku małżeńskiego. Przedstawić można postulat de lege ferenda, aby sąd opiekuńczy na podstawie opinii biegłego sądowego miał możliwość przyznania matce i ojcu, którzy wychowują dziecko, władzy rodzicielskiej, jeżeli ukończyli 16. rok życia.

\section{Bibliografia}

Andrzejewski M., Ochrona praw dziecka w rodzinie dysfunkcyjnej (dziecko - rodzina - państwo), Kraków 2003.

Andrzejewski M., Piecza zastępcza, w: System prawa prywatnego, t. 12. Prawo rodzinne i opiekuńcze, red. T. Smyczyński, Warszawa 2011.

Andrzejewski M., Podstawy prawne ochrony macierzyństwa w Polsce. Status prawny małoletnich i nieletnich matek, w: Sytuacja prawna, społeczna i wychowawcza nieletnich ciężarnych i nieletnich matek przebywających $w$ placówkach resocjalizacyjnych. Raport z realizacji projektu „Chcę być z Tobą MAMO!”, red. A. Sikora, Warszawa 2013.

Andrzejewski M., Prawna ochrona macierzyństwa młodocianych matek, w: Wspótczesne problemy Prawa rodzinnego i spadkowego, red. M. Andrzejewski, K. Dadańska, Szczecin 2014. Andrzejewski M., Relacja rodzice i inne osoby dorosłe a dzieci w świetle nowych przepisów Kodeksu rodzinnego i opiekuńczego i niektórych innych ustaw (wybrane problemy), Acta Iuris Stetinensis 2014, $\mathrm{nr} 6$.

Bidzan M., Nastoletnie rodzicielstwo. Perspektywa psychologiczna, Gdańsk 2013.

Borysiak W., w: Kodeks rodzinny i opiekuńczy. Komentarz, red. J. Wierciński, Warszawa 2014.

Dolecki H., w: Kodeks rodzinny i opiekuńczy. Komentarz, red. H. Dolecki, T. Sokołowski, Warszawa 2013.

Domański M., Zezwolenie na zawarcie małżeństwa kobiecie, która nie ukończyła 18 lat (raport z badania akt sadowych), w: Stosowanie prawa. Ksiega jubileuszowa z okazji XX-lecia Instytutu Wymiaru Sprawiedliwości, red. A. Siemaszko, Warszawa 2011.

Dzieci w Polsce w 2014 roku Charakterystyka demograficzna, https://stat.gov.pl/obszary-tematyczne/ludnosc/ludnosc/dzieci-w-polsce-w-2014-roku-charakterystyka-demograficzna, 20,1.html [dostęp 7.05.2021 r.]. 
Dzietność kobiet w latach 1960-2016, https://stat.gov.pl/obszary-tematyczne/ludnosc/ludnosc/struktura-ludnosci,16,1.html [dostęp: 7.05.2021 r.].

Golec-Grzymek A., Uwagi do nowelizacji Kodeksu rodzinnego i opiekuńczego z 6.11.2008 r., Monitor Prawniczy 2009, nr 19.

Haak H., Pochodzenie dziecka. Komentarz, Toruń 1997.

Haak H., Władza rodzicielska. Komentarz, Toruń 1995.

Haberko J., Cywilnoprawna ochrona dziecka poczętego a stosowanie procedur medycznych, Warszawa 2010.

Ignaczewski J., Pochodzenie dziecka i władza rodzicielska po nowelizacji. Art. 619-1136 KRO, Warszawa 2009.

Ignatowicz J., w: Kodeks rodzinny i opiekuńczy z komentarzem, red. J. Pietrzykowski, Warszawa 1990.

Jędrejek G., Kodeks rodzinny i opiekuńczy. Komentarz aktualizowany, 2019 [baza danych LEX].

Kempińska U., Małżeństwa młodocianych. Ciąża ślub i co dalej...?, Toruń 2012.

Kempińska U., Małżeństwa młodocianych. Przyczyny i konsekwencje, Włocławek 2005.

Ludność i ruch naturalny w 2016 r., https://stat.gov.pl/obszary-tematyczne/ludnosc/ludnosc/ ludnosc-i-ruch-naturalny-w-2016-r-,30,1.html [5.08.2021 r.].

Mościcka L., Diagnoza i prognoza trwałości małżeństw zawieranych za zgoda sądu, Wroclaw 1982.

Nazaruk P., w: Kodeks cywilny. Komentarz, red. J. Ciszewski, P. Nazaruk, 2019 [baza danych LEX], Art. 10.

Pietrzykowski K., w: Kodeks rodzinny i opiekuńczy. Komentarz, red. K. Pietrzykowski, Warszawa 2003.

Ratajczak Ł.P., Rodzicielstwo niepetnoletnich osób, w: Socjalizacja dysocjacyjna w doświadczeniu indywidualnym i społecznym. Inspiracje teoretyczne próby pedagogicznych ingerencji, red. A. Matysiak-Błaszczyk, J. Modrzewski, Poznań-Kalisz 2012.

Ratajczak Ł.P., Ojcostwo w doświadczeniach niepełnoletnich chłopców, Poznań 2016.

Rocznik Demograficzny 2017, https://stat.gov.pl/obszary-tematyczne/roczniki-statystyczne/ roczniki-statystyczne/rocznik-demograficzny-2017,3,11.html [dostęp: 7.05.2021 r.].

Rocznik Demograficzny 2018, https://stat.gov.pl/obszary-tematyczne/roczniki-statystyczne/ roczniki-statystyczne/rocznik-demograficzny-2018,3,12.html, s. 269 [dostęp: 7.05.2021 r.].

Rocznik statystyczny sądownictwa powszechnego i wojskowego 2010-2104, Warszawa 2015.

Sadomski J., w: Kodeks rodzinny i opiekuńczy. Komentarz, red. J. Wierciński, Warszawa 2014.

Smyczyński T., Prawo rodzinne i opiekuńcze, Warszawa 2018.

Sokołowski T., Władza rodzicielska nad dorastajacym dzieckiem, Poznań 1987.

Sokołowski T., Sytuacja prawna małoletniej matki przed urodzeniem dziecka, Ruch Prawniczy, Ekonomiczny i Socjologiczny 1995, z. 2.

Sokołowski T., Prawo rodzinne. Zarys wykładu, Poznań 2010.

Sokołowski T., w: Kodeks cywilny. Komentarz, t. 1. Część ogólna, red. A. Kidyba, 2012 [baza danych LEX].

Sokołowski T., w: Kodeks rodzinny i opiekuńczy. Komentarz, red. H. Dolecki, T. Sokołowski, Warszawa 2013.

Strzebińczyk J., Władza rodzicielska, w: System Prawa Prywatnego, t. 12. Prawo rodzinne i opiekuńcze, red. T. Smyczyński, Warszawa 2003.

Strzebińczyk J., Prawo rodzinne, Warszawa 2013. 
Szukalski P., Urodzenia nastolatek, Demografia i Gerontologia - Biuletyn Informacyjny 2016, nr 6, http://dspace.uni.lodz.pl [dostęp 7.05.2021.].

Trybulska-Skoczelas E., w: Kodeks rodzinny i opiekuńczy. Komentarz, red. J. Wierciński, Warszawa 2014.

Watrakiewicz M., Wiek a zdolność do czynności prawnych, Kwartalnik Prawa Prywatnego 2003, z. 3.

Winiarz J., Gajda J., Prawo rodzinne, Warszawa 2001.

Zieliński A., w: Kodeks postępowania cywilnego. Komentarz, red. A. Zieliński, Warszawa 2008. 